\title{
Productive performance of finishing lambs fed with faveleira fodder salt (Cnidoscolus quercifolius Pohl)
}

\section{Desempenho produtivo de cordeiros em terminação alimentados com sal forrageiro de faveleira (Cnidoscolus quercifolius Pohl)}

\author{
João Vinícius Barbosa Roberto ${ }^{1 *}$; Bonifácio Benicio de Souza²; \\ Gabriel Jorge Carneiro de Oliveira ${ }^{3}$; Jaime Miguel de Araujo Filho ${ }^{4}$; \\ Thaiz Lamy Alves Ribeiro5; Rafael Pádua de Araújo; \\ Thiago Lima da Silva Gomes ${ }^{6}$; Caíque André Cavalcanti da Silva \\ José Lucas Santos Rodrigues ${ }^{7}$; Marcos Lemos Andrade Oliveira ${ }^{8}$
}

\begin{abstract}
This study evaluated food intake and productive performance of crossbred ( $1 / 2$ Santa Inês x $1 / 2$ dorper) lambs supplemented with different levels of faveleira (Cnidoscolus quercifolius Pohl) fodder salt. Thirty male sheep fed tifton grass hay, water, and faveleira fodder salt were randomly allocated into five treatments with six replicates each. The treatments consisted of diets with different inclusion levels of faveleira hay in the fodder salt composition: Treatment 1 (1\% mineral salt $+99 \%$ faveleira hay), Treatment 2 (3\% mineral salt $+97 \%$ faveleira hay), Treatment 3 ( $5 \%$ mineral salt $+95 \%$ faveleira hay), Treatment 4 (7\% mineral salt $+93 \%$ faveleira hay), and Treatment 5 (Control - 100\% mineral salt). Intake of dry matter, tifton hay and water, average daily gain, feed conversion, and feed efficiency were not affected by fodder salt supplementation $(\mathrm{P}>0.05)$. There was a significant difference $(\mathrm{P}<0.05)$ in fodder salt intake between Treatments 4 and 5, and daily intake was higher in animals submitted to Treatment $4\left(61.0 \mathrm{~g} \mathrm{day}^{-1}\right)$. Mineral salt intake increased significantly with increasing mineral salt levels in the diet. However, no significant difference was observed in average daily gain across treatments, indicating that faveleira hay, even in small quantities, and tifton hay were able to meet the nutritional requirements of animals to support a good average daily gain. The inclusion of up to $99 \%$ faveleira hay in fodder salt formulations did not affect voluntary intake of forage, water and dry matter, average daily gain, feed conversion, and feed efficiency. Lambs supplemented with faveleira fodder salt had average daily gains within the optimal range for slaughter and high feed conversion and feed efficiency values. Faveleira was shown to be an effective supplementary feed alternative in sheep.
\end{abstract}

Key words: Consumption. Faveleira. Lamb. Minerals. Weight gain.

\footnotetext{
${ }^{1}$ Discente de Doutorado do programa de Pós-Graduação em Medicina Veterinária, Universidade Federal de Campina Grande, UFCG, CSTR, Patos, PB, Brasil. E-mail: viniciusjv@yahoo.com.br

2 Prof. Dr. Associado IV, Universidade Federal de Campina Grande, CSTR, Patos, PB, Brasil. E-mail: bonif@cstr.ufcg.edu.br

${ }^{3}$ Prof. Associado, Universidade Federal do Recôncavo da Bahia, UFRB. E-mail: gajocaol@yahoo.com.br

${ }^{4}$ Dr. em Zootecnia, UFPB, Pós-doutorando do Programa Nacional de Pós-Doutorado/CAPES, Universidade Federal de Campina Grande, CSTR, Patos, PB, Brasil. E-mail: jaimezoot@gmail.com

${ }^{5}$ Mestres em Zootecnia, pelo programa de Pós-graduação em Zootecnia da UFCG, CSTR, Patos, PB, Brasil. E-mail: thaizz_ ribeiro@hotmail.com; rafaelpaduadearaujopadua@yahoo.com.br

${ }^{6}$ Discente de Mestrado do programa de Pós-graduação em Zootecnia da UFCG, Patos, PB, Brasil. E-mail: thiagovet222@hotmail.com

7 Discentes de Graduação em Medicina Veterinária, UFCG, CSTR, Patos, PB, Brasil. E-mail: caiquecavalcanti@gmail.com; lucasrodrigues.50@hotmail.com

${ }^{8}$ Mestre em Ciência Animal, Universidade Federal do Recôncavo da Bahia, UFRB, Brasil. E-mail: marcos-agr1@hotmail.com

* Author for correspondence
} 


\section{Resumo}

O objetivo deste estudo foi avaliar o consumo e o desempenho produtivo de cordeiros mestiços $1 / 2$ sangue dorper $+1 / 2$ sangue santa inês, suplementados com diferentes níveis de sal forrageiro de faveleira (Cnidoscolus quercifolius Pohl). Utilizou-se 30 ovinos machos, alimentados com feno de capim tífton, água e sal forrageiro de faveleira e distribuídos em um delineamento inteiramente casualizado com cinco tratamentos e seis repetições. Os tratamentos se constituíram de dietas com diferentes proporções de inclusão de feno de faveleira na formulação do sal forrageiro: Tratamento $1(1 \%$ de sal mineral + $99 \%$ de feno de faveleira); Tratamento 2 ( $3 \%$ de sal mineral $+97 \%$ de feno de faveleira); Tratamento 3 (5\% de sal mineral $+95 \%$ de feno de faveleira); Tratamento 4 ( $7 \%$ de sal mineral $+93 \%$ de feno de faveleira) e Tratamento 5 (100 \% de sal mineral). A análise de variância não demonstrou efeito $(\mathrm{P}>0,05)$ da suplementação sobre a ingestão de matéria seca, consumo de feno de tífton, ingestão de água, ganho de peso diário, conversão e eficiência alimentar. Houve diferença $(\mathrm{P}<0,05)$ na ingestão diária de sal forrageiro somente entre o tratamento 4 e o tratamento testemunha, sendo que os animais do tratamento 4 (93\% de feno de faveleira / 7\% de sal mineral) apresentaram maior ingestão (61 g dia $\left.{ }^{-1}\right)$. Já em relação à ingestão de sal mineral, a análise de regressão demonstrou um efeito linear positivo à medida que os níveis de sal mineral foram aumentando. Entretanto, o GPMD foi semelhante entre todos os tratamentos, revelando que mesmo em menores quantidades, o feno de faveleira juntamente com o tífton, foram suficientemente capazes de dispor aos animais uma quantidade adequada de nutrientes, para um bom ganho de peso diário. A inclusão de faveleira de até $99 \%$ na formulação de sal forrageiro, não prejudica o consumo voluntário de volumoso, de água nem a ingestão de matéria seca, assim como também o ganho de peso diário, conversão e eficiência alimentar. Cordeiros suplementados com sal forrageiro de faveleira apresentam níveis de ganho de peso dentro da faixa ótima para o abate, além de bons níveis de conversão e eficiência alimentar, comprovando o potencial desta dicotiledônea como importante alternativa na suplementação de ovinos.

Palavras-chave: Consumo. Faveleira. Ganho de peso. Minerais. Ovino.

\section{Introduction}

Livestock production in northeastern Brazil greatly depends on the breeding of small ruminants, of which sheep are one the most widely distributed. Sheep are also the most heavily exploited livestock animals worldwide because of their rusticity and adaptability to various environmental conditions, from cooler mountainous regions to arid and semiarid areas.

According to the Food and Agriculture Organization of the United Nations (FAO, 2010), Brazil has a significantly large herd of sheep, in excess of 17 million head, of which $56 \%$ are raised in the Northeast region (IBGE, 2010). Sheep are mostly raised extensively in the Caatinga biome and the main limitation to using pastures in Brazil is the seasonality in pasture production, which is caused mainly by climatic factors such as low humidity and intermittent rainfall in the dry season. In addition to the reduced availability of pastures, the lignification of the cell wall and the low protein content and digestibility caused by plant maturation reduce the nutritional value of pastures during the dry season. According to Ben Salem (2010), the low nutritional value and unbalanced nutrient composition of plant resources in the dry season, which demand the use of diet supplementation, is the greatest obstacle to this production system. However, Tosi (1999) argued that continuous growth can be achieved even in unfavorable seasons, provided that animals receive strategic food supplementation that supports moderate, yet significant gains for growth.

In the case of unbalanced diets with reduced nitrogen availability or rich in neutral detergent fiber (NDF), the supply of feed protein degraded in the rumen is limiting for microbial growth. Although protein supplementation can be done with protein concentrates, the production system often becomes impractical due to the high cost of concentrates. 
The use of legume species from the Caatinga in supplement formulations improves animal performance considerably without affecting ecosystem balance (CAVALCANTE et al., 2005). Therefore, the search for low-cost, alternative ingredients that can be produced locally is essential for sustainable livestock production. Thus, fodder salt, a mixture containing mineral salt and hay made of dicot forage species, is a potential alternative for diet supplementation in sheep.

The faveleira or favela (Cnidoscolus quercifolius Pohl) is a xerophytic tree species from the family Euphorbiaceae that is approximately $5.0 \mathrm{~m}$ in height (SANTOS et al., 2006). The species is extremely drought-resistant and, because of stored reserves in stem and root tissues that are allocated for growth of new leaves, flowers, and fruits, it survives under the extreme heat and solar radiation conditions of the Caatinga (MAIA, 2004). According to Arriel et al. (2006), faveleira is an important forage species and food source for wildlife in the semi-arid because of its resilience to harsh environmental conditions. Additionally, the xerophile character of faveleira enables its survival even in periods of prolonged drought, contributing to ecosystem balance and mitigating environmental degradation, as well as enabling sustainable economic exploitation, thus improving the quality of life of the population inhabiting the Caatinga.

In this study, we aimed to evaluate food intake and productive performance of crossbred ( $1 / 2$ Santa Inês x $1 / 2$ dorper) lambs supplemented with varying concentrations of faveleira (Cnidoscolus quercifolius Pohl) fodder salt.

\section{Material and Methods}

The study was conducted in the sheep breeding sector at the Research Center for Semi-arid Development (NUPEÁRIDO), Center for Health and Rural Technology (CSTR), Federal University of Campina Grande (UFCG), Patos, Paraíba, Brazil, between September and October 2012, totaling 55 experiment days, including 10 acclimation days.

The municipality of Patos is located in the hinterland of the state of Paraíba ( $07^{\circ} 01^{\prime} 04^{\prime \prime} \mathrm{S}$, $37^{\circ} 16^{\prime} 40^{\prime}$ ' W; $242 \mathrm{~m}$ elevation) and is characterized by a hot semi-arid climate (BSh) according to the Köppen classification (KÖPPEN, 1948), with seasonal precipitation: one rainy season lasting three to four months having approximately $80 \%$ of the annual rainfall and a dry season in the remaining months. The temperature is megathermal and isothermal, with an annual average of $25-31{ }^{\circ} \mathrm{C}$ and June and July as the coldest months, whereas relative humidity ranges from $40-50 \%$ in the dry season and $80-90 \%$ in the rainy season (GOMES et al., 2013; ARAÚJO FILHO, 2013).

This study used thirty non-castrated crossbred ( $1 / 2$ Santa Inês x $1 / 2$ dorper) male lambs approximately 150 days old with an initial weight of $24.4 \pm 3.32 \mathrm{~kg}$ (mean $\pm \mathrm{sd}$ ), housed in individual $1 \mathrm{~m}^{2}$ pens with feeder, salt feeder, and water drinker, and fed tifton-85 (FCT-85) hay as basic food support to simulate grazing conditions, water, and faveleira (Cnidoscolus quercifolius Pohl) fodder salt ad libitum.

Tifton hay, mineral salt (MS), and faveleira fodder salt were weighed and supplied daily in quantities that allowed for leftovers of $10 \%$ of dry matter (DM) offered the previous day. The voluntary intake of water and food by each animal was calculated from the difference between feed offered and leftovers. Voluntary water intake was corrected for by the average amount of water evaporated from two water drinkers that were kept out of reach of animals.

Prior to the experiment, all animals were identified, dewormed, and vaccinated with polyvalent vaccine against clostridial diseases and rabies vaccine following standard veterinary procedures. To estimate weight gain, all animals were weighed using a sheep scale after a 14-h fasting of liquids and solids at the start and end of the experiment. 
The animals were randomly allocated into five treatments with six replicates each, totaling 30 experimental units. The treatments consisted of experimental diets with different inclusion levels of faveleira hay in the fodder salt composition: Treatment 1 (1\% mineral salt $+99 \%$ faveleira hay), Treatment 2 (3\% mineral salt $+97 \%$ faveleira hay), Treatment 3 (5\% mineral salt $+95 \%$ faveleira hay), Treatment 4 (7\% mineral salt $+93 \%$ faveleira hay), and Treatment 5 (Control -100\% mineral salt).

Tifton hay was ground to avoid feed selection and for accurate measurement of food intake.
Faveleira hay was made from young branches with leaves that were sun-dried for three days. Following grinding, hay was sieved to separate leaves (higher nutritional value) from branches and twigs. Next, hay was milled into fodder and mixed with mineral salt to avoid feed selection.

The mineral salt was a commercial mixture for sheep containing dicalcium phosphate, sodium chloride (43.8\%), magnesium oxide, ventilated sulfur, zinc sulfate, copper sulfate, cobalt sulfate, potassium iodate, manganese sulfate, and sodium selenite. Table 1 shows the guaranteed levels per $100 \mathrm{~g}$ of product and the reference values.

Table 1. Guaranteed levels of macro- and microminerals per $100 \mathrm{~g}$ of mineral salt and reference values.

\begin{tabular}{|c|c|c|c|}
\hline Macromineral (g) & Reference value (RV) & $\begin{array}{c}\text { Amount supplied per } 100 \\
\text { g of supplement }\end{array}$ & $\begin{array}{c}\% \text { of RV supplied per } 100 \\
\text { g of supplement }\end{array}$ \\
\hline Calcium $\left(\mathrm{g} \mathrm{day}^{-1}\right)$ & 14.0 & 11.7 & 83.5 \\
\hline Phosphorus (g day ${ }^{-1}$ ) & 11.0 & 6.0 & 54.5 \\
\hline Sodium $\left(\mathrm{g} \mathrm{day}^{-1}\right)$ & 7.0 & 17.6 & 251.7 \\
\hline Magnesium (g day $\left.{ }^{-1}\right)$ & 9.0 & 0.8 & 8.9 \\
\hline Sulfur $\left(\mathrm{g} \mathrm{day}^{-1}\right)$ & 13.5 & 2.0 & 14.8 \\
\hline \multicolumn{4}{|l|}{ Trace mineral (mg) } \\
\hline Iron $\left(m g\right.$ day $\left.^{-1}\right)$ & 450.0 & - & - \\
\hline Copper (mg day $\left.{ }^{-1}\right)$ & 90.0 & 40.0 & 44.4 \\
\hline Cobalt $\left(\mathrm{mg} \mathrm{day}^{-1}\right)$ & 0.9 & 4.0 & 444.4 \\
\hline Iodine $\left(\mathrm{mg}\right.$ day $\left.^{-1}\right)$ & 4.5 & 7.1 & 158.0 \\
\hline Manganese $\left(m g\right.$ day $\left.^{-1}\right)$ & 180.0 & 135.0 & 75.0 \\
\hline Selenium $\left(m g\right.$ day $\left.^{-1}\right)$ & 0.9 & 1.5 & 165.0 \\
\hline Zinc (mg day $\left.{ }^{-1}\right)$ & 270.0 & 190.0 & 70.4 \\
\hline Vitamin A (IU day $\left.{ }^{-1}\right)$ & 20,000 & - & - \\
\hline Vitamin D3 (IU day ${ }^{-1}$ ) & 2,500 & - & - \\
\hline Vitamin E (IU day $\left.{ }^{-1}\right)$ & 350.0 & - & - \\
\hline
\end{tabular}

The analysis of the chemical composition of tifton hay and faveleira hay were conducted in the Laboratory of Animal Nutrition at the Center for Health and Rural Technology (CSTR/UFCG) according to the methodology described by Silva and Queiroz (2002) (Table 2). 
Table 2. Chemical composition of ingredients used in experimental diets.

\begin{tabular}{lcc}
\hline Component (\% DM) & Tifton hay & Faveleira hay \\
\hline Dry matter & 97.73 & 95.11 \\
Organic matter & 90.89 & 89.33 \\
Ash & 9.11 & 10.67 \\
Crude protein & 7.49 & 11.32 \\
Ether extract & 6.67 & 6.51 \\
Gross energy & 3.84 & 3.797 \\
Neutral detergent fiber & 69.00 & 41.86 \\
Acid detergent fiber & 36.11 & 35.25 \\
Lignin & 31.52 & 25.58 \\
\hline
\end{tabular}

The following variables were evaluated: dry matter intake $\left(\mathrm{kg} \mathrm{day}^{-1}\right)$, tifton hay intake $\left(\mathrm{kg} \mathrm{day}^{-1}\right)$, fodder salt intake, mineral salt intake, water intake, dry matter intake/body weight ratio, average daily gain, initial and final weight, feed conversion, and feed efficiency.
The data were analyzed using analysis of variance (ANOVA) and treatment means were compared using the Tukey's test at the 5\% significance level. To the average of the different levels of faveleira fodder salt, was used polynomial regression analysis. All analyses were performed using SAS software (SAS, 2003).

\section{Results and Discussion}

Dry matter intake was not affected $(\mathrm{P}>0.05)$ by faveleira fodder salt supplementation (Table 3 ). Average DM intake $\left(0.909 \mathrm{~kg} \mathrm{day}^{-1}\right)$ was lower than the value recommended by the National Research Council (NRC, 1985) for sheep with an average weight of $20-30 \mathrm{~kg}\left(1.3 \mathrm{~kg} \mathrm{day}^{-1}\right)$. This result was likely due to the low digestibility of diets, which mainly consisted of forage species that may limit consumption (CHURCH, 1993), and the low protein $(7.49 \%)$ and high neutral detergent fiber (NDF = $69 \%$ ) content in tifton hay.

Table 3. Effect of fodder salt composition (faveleira hay:mineral salt ratio) on daily dry matter intake (DMI), tifton hay intake (THI), faveleira fodder salt intake (FFSI), mineral salt intake (MSI), water intake (WI), and dry matter intake:body weight ratio (DM:BW).

\begin{tabular}{|c|c|c|c|c|c|c|c|}
\hline \multirow{2}{*}{ Parameter } & \multicolumn{5}{|c|}{ Faveleira hay:mineral salt ratio (\%) } & \multirow{2}{*}{ CV $(\%)$} & \multirow{2}{*}{ Mean } \\
\hline & 99:1 & 97:3 & 95:5 & 93:7 & $0: 100$ & & \\
\hline DMI (kg day $\left.{ }^{-1}\right)$ & $0.826 \mathrm{~A}$ & $0.985 \mathrm{~A}$ & $0.898 \mathrm{~A}$ & $0.924 \mathrm{~A}$ & $0.913 \mathrm{~A}$ & 15.17 & 0.909 \\
\hline DM:BW (\%) & $3.10 \mathrm{~A}$ & $3.38 \mathrm{~A}$ & $3.24 \mathrm{~A}$ & $3.17 \mathrm{~A}$ & $3.34 \mathrm{~A}$ & 9.72 & 3.24 \\
\hline THI $\left(\mathrm{kg}\right.$ day $\left.^{-1}\right)$ & $0.781 \mathrm{~A}$ & $0.937 \mathrm{~A}$ & $0.866 \mathrm{~A}$ & $0.862 \mathrm{~A}$ & $0.897 \mathrm{~A}$ & 15.89 & 0.869 \\
\hline FFSI $\left(\mathrm{kg} \mathrm{day}^{-1}\right)$ & $0.045 \mathrm{AB}$ & $0.048 \mathrm{AB}$ & $0.031 \mathrm{AB}$ & $0.061 \mathrm{~A}$ & $0.016 \mathrm{~B}$ & 51.59 & 0.040 \\
\hline MSI (g day $\left.{ }^{-1}\right)$ & $0.456 \mathrm{C}$ & $1.463 \mathrm{BC}$ & $1.570 \mathrm{BC}$ & $4.318 \mathrm{~B}$ & $16.195 \mathrm{~A}$ & 46.20 & 4.80 \\
\hline \multirow[t]{2}{*}{ WI $\left(\mathrm{kg} \mathrm{day}^{-1}\right)$} & $2.622 \mathrm{~A}$ & $2.396 \mathrm{~A}$ & $1.988 \mathrm{~A}$ & $2.202 \mathrm{~A}$ & $2.363 \mathrm{~A}$ & 17.39 & 2.314 \\
\hline & \multicolumn{6}{|c|}{ Regression equation } & $\mathbf{r}^{2}$ \\
\hline DMI (kg day $\left.{ }^{-1}\right)$ & \multicolumn{6}{|c|}{$Y=0.876$} & - \\
\hline DM:BW (\%) & \multicolumn{6}{|c|}{$\mathrm{Y}=3.222$} & - \\
\hline THI $\left(k g\right.$ day $\left.^{-1}\right)$ & \multicolumn{6}{|c|}{$Y=0.834$} & - \\
\hline FFSI $\left(\mathrm{kg} \mathrm{day}^{-1}\right)$ & \multicolumn{6}{|c|}{$Y=0.040$} & - \\
\hline MSI (g day ${ }^{-1}$ ) & \multicolumn{6}{|c|}{$Y=-0.386+0.584 x$} & 0.619 \\
\hline WI $\left(\mathrm{kg} \mathrm{day}^{-1}\right)$ & \multicolumn{6}{|c|}{$Y=2.635-0.083 x$} & 0.176 \\
\hline
\end{tabular}

Means followed by the same letter in a row are not significantly different (Tukey's test, $p>0.05$ ). 
According to Cruz et al. (2010), feeds with NDF content $>60 \%$ can result in lower DM intake and feed consumption due to the physical limitation of the rumen, thus reducing food passage rate in the digestive tract. Nevertheless, we opted to provide a product with such characteristics to simulate grazing in drought conditions.

Baroni (2011) evaluated nutrient digestibility in sheep fed gliricidia (Gliricidia sepium (Jack.) Walp) fodder salt formulated with different $\mathrm{NaCl}$ concentrations and, contrary to this study, found that DM intake was significantly affected by diet supplementation $(\mathrm{P}<0.05)$, with the highest average DM intake values (980.0, 881.4, 934.4, and 842.6 g) in diets with $1,3,5$, and $7 \% \mathrm{NaCl}$, respectively, whereas the lowest DM intake (710 g) was observed in control animals (100\% mineral salt).

Similar results were reported by Gonçalves et al. (2008), who evaluated fodder salts of aerial parts of cassava (Manihot esculenta), and leucaena (Leucaena leucocephala) in crossbred Santa Inês lambs and found DM intake values of 913.59 and $995.47 \mathrm{~g} \mathrm{day}^{-1}$, respectively, whereas control animals (without supplementation) consumed only 432.13 g DM day $^{-1}$.

Average DM intake was $3.24 \%$ of live body weight, which is close to the $3.91 \%$ recommended by the NRC (2006) for $20 \mathrm{~kg}$ sheep. Because diets consisted of forage only without concentrate supplementation, DM intake as a percentage of live body weight in our study was satisfactory.

Tifton hay intake was not affected by faveleira fodder salt supplementation $(\mathrm{P}>0.05)$; average intake in our study was $0.869 \mathrm{~kg} \mathrm{day}^{-1}$, which is higher than the $0.773 \mathrm{~kg}$ day $^{-1}$ reported by Baroni (2011), who also found no effect of varying gliricidia levels in diet formulations on tifton intake.

Similar results were reported by Silva et al. (2006) and Cirne et al. (2012), who also found no effect of fodder salts on forage intake. Nevertheless, Cirne et al. (2012) reported a tifton intake value of 0.972 $\mathrm{kg}$ day $^{-1}$, which is higher than the value observed in the current study. The high intake of tifton grass hay may have been due to the good palatability and acceptability of the species by animals.

Silva et al. (2006) used pangola (Digitaria decumbens Stent.) grass as forage and reported an intake of $0.557 \mathrm{~kg} \mathrm{day}^{-1}$, which is lower than the value observed in this study. This difference may be explained by the lower acceptability of pangola grass by animals compared to tifton grass.

There was a significant difference in fodder salt intake $(\mathrm{P}<0.05)$ between the treatment with the highest mineral salt content (Treatment 4: 93\% faveleira hay $+7 \%$ mineral salt) and the Control treatment (Treatment 5: 100\% mineral salt), but no difference across the other faveleira fodder salt treatments $(\mathrm{P}>0.05)$.

Average fodder salt intake was $40 \mathrm{~g} \mathrm{day}^{-1}$, which is lower than the values reported by Cirne et al. (2012) and Silva et al. (2006) for gliricidia fodder salt (98 $\mathrm{g} \mathrm{day}^{-1}$ and $65.85 \mathrm{~g} \mathrm{day}^{-1}$, respectively).

According to Lopes et al. (2000), consumption of multiple mixtures containing 30\% common salt by sheep should be around 50-80 $\mathrm{g} \mathrm{day}^{-1}$. In the current study, average fodder salt intake (40 $\mathrm{g}$ day ${ }^{-}$ $\left.{ }^{1}\right)$ was lower than the recommended minimum for multiple mixtures. Even though faveleira has great potential as forage and good forage characteristics (PEREIRA et al., 2012), the low intake of faveleira fodder salt in our study may have been due to the low initial acceptability of the species, which is likely caused by its odor active volatile compounds, and the greater palatability and acceptability of tifton hay in diets.

Mineral salt intake increased from 0.4 to $16.12 \mathrm{~g}$ day $^{-1}$ with increasing mineral salt levels in the fodder salt. In fact, mineral salt intake was significantly affected by mineral salt supplementation ( $\mathrm{P}<$ 0.05; Table 3) and average intake was highest in the Control treatment. This is an expected result considering that diets in that treatment were supplemented with $100 \%$ mineral salt. Also, regression analysis showed a positive linear effect 
of mineral salt content on mineral salt intake.

Even though mineral salt intake increased with increasing mineral salt levels, no significant difference was observed in average daily gain (ADG) across treatments (Table 4). For example, animals fed with diets with lower or higher faveleira

$$
6,16 \mathrm{~A}-6,42 \mathrm{~A}-6,48 \mathrm{~A}-6,34 \mathrm{~A}-5,42 \mathrm{~A} \text {. }
$$

Table 4. Effect of fodder salt composition (faveleira hay:mineral salt ratio) on average daily gain (ADG), initial body weight (IBW), final body weight (FBW), feed conversion (FC), and feed efficiency (FE).

\begin{tabular}{|c|c|c|c|c|c|c|c|}
\hline \multirow{2}{*}{ Parameter } & \multicolumn{5}{|c|}{ Faveleira hay:mineral salt ratio (\%) } & \multirow{2}{*}{ CV (\%) } & \multirow{2}{*}{ Mean } \\
\hline & 99:1 & $97: 3$ & 95:5 & 93:7 & $0: 100$ & & \\
\hline ADG $(g)$ & $152 \mathrm{~A}$ & $157 \mathrm{~A}$ & $152 \mathrm{~A}$ & $154 \mathrm{~A}$ & $170 \mathrm{~A}$ & 25.27 & 157 \\
\hline IBW (kg) & $23.41 \mathrm{~A}$ & $25.51 \mathrm{~A}$ & $24.28 \mathrm{~A}$ & $25.83 \mathrm{~A}$ & $23.36 \mathrm{~A}$ & 13.86 & 24.48 \\
\hline FBW (kg) & $30.26 \mathrm{~A}$ & $32.61 \mathrm{~A}$ & $31.11 \mathrm{~A}$ & $32.76 \mathrm{~A}$ & $31.03 \mathrm{~A}$ & 11.6 & 31.56 \\
\hline $\mathrm{FC}\left(\mathrm{kg} \mathrm{DM} \mathrm{kg} \mathrm{ADG}^{-1}\right)$ & $6.16 \mathrm{~A}$ & $6.42 \mathrm{~A}$ & $6.48 \mathrm{~A}$ & $6.34 \mathrm{~A}$ & $5.42 \mathrm{~A}$ & 32.91 & 6.16 \\
\hline \multirow[t]{2}{*}{ FE $(\%)$} & $18.86 \mathrm{~A}$ & $16.52 \mathrm{~A}$ & $17.16 \mathrm{~A}$ & $16.66 \mathrm{~A}$ & $19.21 \mathrm{~A}$ & 31.37 & 17.68 \\
\hline & \multicolumn{6}{|c|}{ Regression equation } & $\mathbf{r}^{2}$ \\
\hline ADG (g) & \multicolumn{6}{|c|}{$\mathrm{Y}=154$} & - \\
\hline IBW $(\mathrm{kg})$ & \multicolumn{6}{|c|}{$Y=30.92$} & - \\
\hline FBW (kg) & \multicolumn{6}{|c|}{$Y=39.96$} & - \\
\hline $\mathrm{FC}\left(\mathrm{kg} \mathrm{DM} \mathrm{kg} \mathrm{ADG}{ }^{-1}\right)$ & \multicolumn{6}{|c|}{$\mathrm{Y}=6.313$} & - \\
\hline $\mathrm{FE}(\%)$ & \multicolumn{6}{|c|}{$Y=13.243$} & - \\
\hline
\end{tabular}

Means followed by the same letter in a row are not significantly different (Tukey's test, $\mathrm{p}>0.05$ ).

Baroni (2011) evaluated the effect of mineral salt content on gliricidia fodder salt in sheep and reported an average MS intake of 5.3-18.2 $\mathrm{g} \mathrm{day}^{-1}$, which is above the range observed in this study. The mineral salt intake of 1.46 and $1.57 \mathrm{~g}_{\text {day }}{ }^{-1}$ by animals in Treatments 2 (97\% faveleira hay) and 3 (95\% faveleira hay), respectively (Table $3)$, was close to the $1.98 \mathrm{~g} \mathrm{day}^{-1}$ reported by Silva et al. (2006), who evaluated gliricidia fodder salt supplementation in crossbred Santa Inês animals. The average MS intake of $16.2 \mathrm{~g} \mathrm{day}^{-1}$ by animals fed MS only was higher than the $10 \mathrm{~g} \mathrm{day}^{-1}$ per animal estimated by Araújo Filho et al. (2000). According to Teixeira (2001), minerals are nutritionally essential for ruminants and their gut microorganisms and have a direct effect on growth, fattening, milk production, reproduction, wool production, and maintenance of vital processes in sheep.

Average water intake was $2.314 \mathrm{~kg}$ day $^{-1}$ and water intake was not affected by faveleira fodder salt supplementation $(\mathrm{P}>0.05)$. However, regression analysis showed that fodder salt supplementation had a negative linear effect on water intake in Treatments 1, 2, and 3 and a positive linear effect in Treatments 3, 4, and 5. These results indicate that water intake increases with increasing mineral salt levels up to $5 \%$ (5\% mineral salt + 95\% faveleira hay) then decreases beyond that 5\% threshold. The average water intake of $2.3 \mathrm{~kg} \mathrm{day}^{-1}$ for an average DM intake of $0.909 \mathrm{~kg} \mathrm{day}^{-1}$ (Table 3 ) is close to the range recommended by Teixeira (2003), which is a minimum $2 \mathrm{~L}$ of water per $\mathrm{kg}$ 
DM consumed for feedlot lambs, whereas the NRC (2007) recommends $0.800 \mathrm{~kg}$ day $^{-1}$. Thus, water intake in our study was significantly higher than NRC recommendations.

The high water intake in our study may be explained by the type of diet fed to animals, which were hay-based diets rich in mineral salt, ingredients that are known to increase water consumption. In fact, Souza et al. (2010) evaluated feed intake behavior and water intake in goats and sheep fed cassava hay and silage and found that water intake was higher in animals fed cassava hay than in animals fed cassava silage. Gonçalves et al. (2008) evaluated the use of fodder salts of various xerophyte species in sheep and reported water intake values of 2.21, 3.39, 3.401, 2.942, 2.145, and $2.178 \mathrm{~kg} \mathrm{day}^{-1}$ for pangola grass (control) and fodder salts of leucaena, aerial parts of cassava, bravo beans (Macroptilium bracteatum), barriguda (Ceiba samauma), and quipé (Piptadenia moniliformis), respectively. According to Berchielli et al. (2006), water intake in ruminants is also affected by crude protein intake, which increases water requirements because of the increased caloric demand for protein digestion. Moreover, voluntary water intake in sheep is determined by intake levels of dry matter, crude protein, and mineral salt (NRC, 1985).

Average daily gain, initial body weight, final body weight, feed conversion, and feed efficiency (Table 4) were not affected by mineral salt content in fodder salts $(\mathrm{P}>0.05)$. The average daily gain of $157.0 \mathrm{~g}$ observed in this study is higher than the $74.64,85.0,48.57,25.71$, and $21.42 \mathrm{~g}$ for fodder salts of leucaena, aerial parts of cassava, bravo beans, barriguda, and quipé, respectively, reported by Gonçalves et al. (2008). Silva et al. (2006) evaluated fodder salts of the same dicot species and also reported lower ADG values (109.52 and 85.19 $\mathrm{g} \mathrm{day}^{-1}$ ) than the ones found in this study. Similarly, Sousa (2014), Costa et al. (2012), and Manera et al. (2014) also reported lower ADG values than the value reported in the current study.
Even though animals in our study were fed forage only without concentrate supplementation, ADG values were higher than those in various studies using concentrate supplementation, suggesting that sheep diets formulated with faveleira fodder salt and tifton hay provide high weight gains, favoring the use of faveleira as a good alternative in sheep feeding.

Initial body weight (IBW: $24.5 \pm 3.3 \mathrm{~kg}$ ) and final body weight (FBW: $31.6 \pm 1.08 \mathrm{~kg}$ ) were not significantly different across treatments $(\mathrm{P}>$ 0.05). According to Silva and Nóbrega (2008), depending on development phase, physiological condition, and level of production, animals have different nutritional requirements that must be met so that they can fully express their productive and reproductive potential. Thus, faveleira fodder salt supplementation likely provided adequate nutrient levels for satisfactory growth performance of lambs in this study, resulting in satisfactory weight gain and final body weight. The optimal slaughter weight for Santa Inês lambs is $15-35 \mathrm{~kg}$ according to Santos et al. (2001). Thus, FBW in our study are within the slaughter weight range for Santa Inês lambs.

Feed conversion (FC) and feed efficiency (FE) were not significantly different across treatments $(\mathrm{P}$ $>0.05)$. FC and FE are two important parameters used in the evaluation of diets. According to Packer and Haddad (1995) and Silveira and Domingues (1995), FC and FE depend on factors such as type of feed, environmental conditions, body weight during the study period, composition of gain, and animal health. Because age and rearing conditions were similar for all animals in this study, FC and FE values were affected by type of feed only and are a reflection of the energy levels in diets.

Average FC in this study (6.16) was better than the 14.25 reported by Gonçalves et al. (2008) for crossbred Santa Inês lambs fed pangola grass and fodder salts of different dicot species. Cunha et al. (2008) evaluated the performance of Santa Inês lambs fed whole cottonseed and reported FC 
values of $6.01,6.71,7.62$, and 6.9 for diets with $0,20,30$, and $40 \%$ whole cottonseed, which are close to the value recorded in this study. Average FE in our study (17.68\%) was similar to the values estimated in studies that evaluated more complex diets containing concentrate supplements in addition to forage (ÍTAVO et al., 2006; MEDEIROS et al., 2007) and higher than the values estimated in studies that used fodder salt supplementation in sheep diets (SILVA et al., 2006; GONÇALVES et al., 2008; CIRNE et al., 2012).

In our study, the lack of effect of fodder salt composition on FC and FE indicates that the inclusion of different faveleira hay levels in fodder salt formulations and the use of faveleira as a supplement did not affect the ability of lambs to convert ingested food into product, i.e., meat per $\mathrm{kg}$ DM consumed, supporting the use of faveleira as an effective supplementary feed alternative in sheep diets.

\section{Conclusions}

This study showed that the inclusion of up to 99\% faveleira hay in fodder salt formulations did not affect voluntary forage intake, water intake, or dry mater intake. Importantly, faveleira hay, even in small amounts, and tifton hay used in fodder salt formulations were able to meet the nutrient requirements of animals for a good average daily gain. Lambs supplemented with faveleira fodder salt had average daily gains within the optimal range for slaughter and high feed conversion and feed efficiency values. Therefore, faveleira was shown an effective supplementary feed alternative in sheep.

\section{References}

ARAÚJO FILHO, J. A. Manejo pastoril sustentável da caatinga. Recife: Projeto Dom Helder Camara, 2013. $200 \mathrm{p}$.
ARAÚJO FILHO, J. A.; ALVES, J. U.; BRAGA JUNIOR, W. G. Trabalhador na ovinocultura. Brasília: SEBRAE /SUDENE/SENAR, 2000. 88 p.

ARRIEL, E. F.; PAULA, R. C.; RODRIGUES, T. J. D.; BAKKE, O. A.; ARRIEL, N. H. C. Divergência genética entre progênies de Cnidoscolus phyllacanthus submetidas a três regimes hídricos. Científica, Jaboticabal, v. 34, n. 2, p. 229-237, 2006.

BARONI, M. R. Consumo, digestibilidade de nutrientes e comportamento ingestivo em ovinos alimentados com sal forrageiro de gliricídia (gliricídia sepium (jacq.) Walp). 2011. Dissertação (Mestrado em Ciência Animal) - Universidade Federal do Recôncavo da Bahia, Cruz das Almas, Bahia.

BEN SALEM, H. Nutritional management to improve sheep and goat performances in semiarid regions. Revista Brasileira de Zootecnia, Viçosa, MG, v. 39, p. 337-347, 2010. Suplemento Especial.

BERCHIELLI, T. T.; PIRES, A. V.; OLIVEIRA, S. G. Nutrição de ruminantes. Jaboticabal: Funep, 2006. 583 p.

CAVALCANTE, M. A. B.; PEREIRA, O. G.; VALADARES FILHO, S. C. Níveis de proteína bruta em dietas para bovinos de corte: consumo e digestibilidades total e parcial dos nutrientes. Revista Brasileira de Zootecnia, Viçosa, MG, v. 34, n. 6, p. 2200-2208, 2005.

CHURCH, C. D. (Ed.). El ruminante: fisiologia digestiva y nutrición. Zaragoza: Acribia, 1993. 645 p.

CIRNE, L. G. A.; BARONI, M. R.; OLIVEIRA, G. J. C.; JAEGER, S. M. P. L.; BAGALDO, A. R.; LEITE, M. C. P. Características produtivas de cordeiros em confinamento suplementados com sal forrageiro de Gliricidia sepium (Jacq.) Walq. Magistra, Cruz das Almas, v. 24, n. 1, p. 1-6, 2012.

COSTA, D. S.; COSTA, M. D.; SILVA, F. V.; ROCHA JÚNIOR, V. R.; CARVALHO, Z. G.; TOLENTINO, D. C.; LEITE, J. R. A. Desempenho ponderal de cordeiros Santa Inês e F1 Dorper x Santa Inês em pastagens naturais. Revista Brasileira de Saúde e Produção Animal, Salvador, v. 13, n. 1, p. 237-243, jan./mar. 2012.

CRUZ, B. C. C.; SANTOS-CRUZ, C. L.; PIRES, A. J. V.; ROCHA, J. B.; SANTOS, S.; BASTOS, M. P. V. Composição bromatológica da silagem de capimelefante com diferentes proporções de casca desidratada de maracujá (Passiflora edulis Sims f. flavicarpa). Revista Brasileira de Ciências Agrárias, Recife, v. 5, n. 3, p. 434440, 2010. 
CUNHA, M. G. G.; CARVALHO, F. F. R.; VÉRAS, A. S. C.; BATISTA, A. M. V. Desempenho e digestibilidade aparente em ovinos confinados alimentados com dietas contendo níveis crescentes de caroço de algodão integral. Revista Brasileira de Zootecnia, Viçosa, MG, v. 37, n. 6, p. 1103-1111, 2008.

FOOD AND AGRICULTURE ORGANIZATION OF THE UNITED NATIONS - FAO. 2010. Disponível em: <http://faostat.fao.org/site/573/default.aspx\#ancor>. Acesso em: 15 dez. 2014.

GOMES, L. C. F.; SANTOS, C. A. C.; ALMEIDA, H. A. Balanço de energia à superfície para a cidade de patos$\mathrm{pb}$ usando técnicas de sensoriamento remoto. Revista Brasileira de Geografia Física, Recife, v. 6, n. 1, p. 1528, 2013.

GONÇALVES, G. S.; OLIVEIRA, G. J. C.; JAEGER, S. M. P. L; OLIVEIRA, R. L.; CAMPOS, J. O.; REZENDE, L. S. Desempenho de cordeiros alimentados com dietas contendo sal forrageiro de espécies vegetais xerófitas. Revista Brasileira de Zootecnia, Viçosa, MG, v. 37, n. 12, p.2185-2190, 2008.

INSTITUTO BRASILEIRO DE GEOGRAFIA E ESTATÍSTICA - IBGE. Produção da pecuária municipal. Rio de Janeiro: IBGE, v. 38, 2010. p. 1-65.

ÍTAVO, C. C. B. F.; MORAIS, M. G.; ÍTAVO, L. C. V.; SOUZA, A. R. D. L.; OSHIRO, M. M.; BIBERG, F. A.; COSTA, C.; JOBIM, C. C.; LEMPP, B. Efeitos de diferentes fontes de concentrado sobre o consumo e a produção de cordeiros na fase de terminação. Revista Brasileira de Zootecnia, Viçosa, MG, v. 35, n. 1, p. 139146, 2006.

KÖPPEN, W. Climatologia: com un estudio de lós climas de la tierra. [S.1.]: Fundo de Cultura Econômica, 1948. $466 \mathrm{p}$.

LOPES, H. O. S.; TOMICH, T. R.; GONÇALVES, L. C.; BORGES, I. Recomendações técnicas para a utilização da ureia pecuária na alimentação animal. Brasília: Embrapa Cerrados, 2000. 35 p.

MAIA, G. M. Caatinga: árvores e arbustos e suas utilidades. São Paulo: D \& Z Computação Gráfica e Editora, 2004. 413 p.

MANERA, D. B.; VOLTOLINI, T. V.; YAMAMOTO, S. M.; ARAÚJO, G. G. L.; SOUZA, R. A. Desempenho produtivo de ovinos em pastejo suplementados com concentrados contendo coprodutos do processamento de frutas. Semina: Ciências Agrárias, Londrina, v. 35, n. 2, p. 1013-1022, 2014.
MEDEIROS, G. R.; CARVALHO, F. F. R.; FERREIRA, M. A.; BATISTA, A. M. V.; ALVES, K. S.; MAIOR JÚNIOR, R. J. S.; ALMEIDA, S. C. Efeito dos níveis de concentrado sobre o desempenho de ovinos Morada Nova em confinamento. Revista Brasileira de Zootecnia, Viçosa, MG, v. 36, n. 4, p. 1162-1171, 2007. Suplemento.

NATIONAL RESEARCH COUNCIL - NRC. Nutrient requeriments of small ruminants. Washington: National Academic Press, 2006. 362 p.

. Nutrient requirements of small ruminants: sheep, goats, cervids, and new world camelids. Washington, D. C.: National Academy Press, 2007. 362 p.

Nutrient requirements of sheep. $5^{\text {th }}$ ed. Washington, D. C.: National Academy of Science, 1985. $49 \mathrm{p}$.

PACKER, I. U.; HADDAD, C. M. Interrelações entre genética e nutrição de bovinos. In: PEIXOTO, A. M.; MOURA, J. C.; FARIA, V. P. (Ed.). Nutrição de bovinos: conceitos básicos e aplicados. Piracicaba: Fundação de Estudos Agrários Luiz de Queiroz, 1995. p. 515-526.

PEREIRA, V. L. A.; ALVES, F. A. L.; SILVA, V. M.; OLIVEIRA, J. C. Valor nutritivo e consumo voluntário do feno de faveleira fornecido a ovinos no semiárido pernambucano. Revista Caatinga, Mossoró, v. 25, n. 3, p. 96-101, 2012.

SANTOS, C. L.; PÉREZ, J. R. O.; MUNIZ, J. A.; GERASEEV, L. C.; SIQUEIRA, E. R. Desenvolvimento relativo dos tecidos ósseo, muscular e adiposo dos cortes da carcaça de cordeiros Santa Inês. Revista Brasileira de Zootecnia, Viçosa, MG, v. 30, n. 2, p. 487-492, 2001.

SANTOS, J. C. O.; NUNES, L. D.; DANTAS, J. P.; NÓBREGA, S. B. P.; PRASAD, S. Análise Química e bromatológica da forragem da faveleira (Cnidoscolus quercifolius). Periódico Tchê Química, Porto Alegre, v. 3, n. 5, p. 31-42, 2006.

SILVA, A. M. de A.; NÓBREGA, G. H. da. Exigências nutricionais de ruminantes em pastejo. In: SIMPÓSIO EM SISTEMAS AGROSILVIPASTORIS NO SEMIÁRIDO, 1., 2008, Campina Grande. Anais... Campina Grande: Universidade Federal de Campina Grande, 2008. p. 1-18.

SILVA, A. M.; OLIVEIRA, G. J. C.; JAEGER, S. M. P.; ALMEIDA, A. M. M.; STRADA, E. S. O.; Consumo de sal forrageiro por ovinos deslanados em confinamento. Magistra, Cruz das Almas, v. 18, n. 1, p. 1-6, 2006.

SILVA, D. J.; QUEIROZ, A. C. de. Análises de alimentos: métodos químicos e biológicos. 3. ed. Viçosa, MG: Editora UFV, 2002. 235 p. 
SILVEIRA, A. C.; DOMINGUES, C. A. C. Alimentação e conversão de bovinos puros e cruzados. In: PEIXOTO, A. M.; MOURA, J. C.; FARIA, V. P. (Ed.). Nutrição de bovinos: conceitos básicos e aplicados. Piracicaba: Fundação de Estudos Agrários Luiz de Queiroz, 1995. p. 291-320.

SOUSA, V. S. Desempenho, características de carcaça e parâmetros sanguíneos em ovinos Santa Inês suplementados com Crambe abyssinica. 2014. Tese (Doutorado em Ciências Animais) - Faculdade de Agronomia e Medicina Veterinária da Universidade de Brasília, Brasília.

SOUZA, E. J. O.; GUIM, A.; BATISTA, A. M. V.; ALBUQUERQUE, D. B.; MONTEIRO, C. C. F.; ZUMBA, E. R. F.; TORRES, T. R. Comportamento ingestivo e ingestão de água em caprinos e ovinos alimentados com feno e silagem de Maniçoba. Revista Brasileira de Saúde e Produção Animal, Salvador, v. 11, n. 4, p. 1056-1067, 2010.
STATISTICAL ANALYSIS SYSTEM INSTITUTE - SAS. Statistical analisys system. SAS user's guide: statistics. Versão 9.1. Cary: SAS, 2003.

TEIXEIRA, J. C. Alimentos e alimentação dos animais. Lavras: UFLA, 2003. 241 p.

$183 \mathrm{p}$. . Nutrição de ruminantes. Lavras: UFLA, 2001.

TOSI, H. Suplementação mineral em pastagem. In: SIMPÓSIO SOBRE MANEJO DA PASTAGEM, 1999, Piracicaba. Anais... Piracicaba: Fundação de Estudos Agrários Luiz de Queiroz, 1999. 159 p. 
